\title{
EFFECTS OF SEVERE PROTEIN RESTRICTION IN LEVELS OF PARASITEMIA AND IN MORTALITY OF MICE ACCUTELY INFECTED WITH TRYPANOSOMA CRUZI
}

\author{
Nildete G.L. Gomes, Fausto E.L. Pereira, Gisele C.S. Domingues and Jesse \\ R. Alves
}

\begin{abstract}
Adult mice were submitted to different degrees of protein restriction for five weeks $(4.75$, 9.5, 14.25 and $19 \%$ of protein in isocaloric diets with normal content of mineral and vitamins), being subsequently infected with two strains of Trypanosoma cruzi: $10^{5}$ trypomastigotes of $Y$ strain or $10^{4}$ trypomastigotes of CL strain. The same diet was maintained for all animals and the infection was followed up by evaluation of blood parasites, mortality and intensity of lesions in the heart and skeleton muscle. Onty severe protein restriction (4.75\%) induced decrease in resistance to the infection with both the $Y$ and $C L$ strains of $\mathrm{T}$. cruzi, which resulted in higher parasitemia and mortality. The inflammatory lesions in heart and skeleton muscle were less extensive in groups with severe protein restriction despite the increased number of parasite in muscle cells. Depression of immune mechanisms could be responsible for the reduced resistance and reduced inflammatory reaction after $\mathrm{T}$. cruzi infection in severely protein restricted animals.
\end{abstract}

Key-words: Malnutrition. Chagas' disease. Trypanosoma cruzi.

Clinical and epidemiological observations suggest that malnutrition, mainly protein deprivation, plays an important role in the development of infections which include protozoal diseases ${ }^{2} 8$. Although most reports show enhancement of infections in malnourished patients or experimental animals, some observations have shown increased resistance to malaria infection in rats that were submitted to protein restriction ${ }^{3} 10$. Moreover, while protein deprived mice infected with Leishmania mexicana showed arrest of lesion growth during the five initial weeks of infection, with subsequent development of non-healing lesions, normally nourished mice developed progressively healing lesions ${ }^{9}$.

The effects of malnutrition on the evolution of Chagas' disease has not yet been evaluated. There are few reports showing enhancement of parasitemia and more severe lesions in the heart of infected rats submitted to diets with deficient amounts of thiamine, riboflavine, pantothenate or pyridoxine $e^{16171819}$.

\footnotetext{
Departamento de Patologia, Centro Biomédico, Universidade Federal do Espírito Santo. Vitória, ES.

Address to: Dr. Fausto E.L. Pereira. Centro Biomédico/UFES. Caixa Postal 780, 29060-970 Vitória, ES, Brasil.

Recebido para publicação em $05 / 11 / 92$.
}

Other aspects have been evaluateu as the demonstration that protein malnutrition delays the recovery of cardiac adrenalin in chronic experimental Chagas' disease in rats $^{5}$.

Because the few informations about the relationship between nutrition and Chagas' disease, we decide to investigate the course of Trypanosoma cruzi infection (parasitemia, mortality and intensity of lesions in heart and skeleton muscle) in normally nourished (19\% of protein) and in mice maintained on isocaloric diets with $14.25,9.5$ or $4.75 \%$ of protein.

\section{MATERIAL AND METHODS}

Animals and Trypanosoma cruzistrains. Adult male outbred albino mice weighing $23-25 \mathrm{~g}$, were used in the experiments. The infection was done by i.p. route with two strains of Trypanosoma cruzi: $10^{4}$ blood trypomastigotes of the CL strain or $10^{5}$ blood trypomastigotes of the Y strain. These two strains of $T$. cruzi have distinct tissular tropism: the $\mathrm{CL}$ strain is myotropic, with high parasitism of muscle cells while the Y strain has high tropism for the mononuclear phagocytic cells? 
Gomes NGL, Pereira FEL, Domingues GCS, Alves JR. Effects of severe protein restriction in levels of parasitemia and in mortality of mice accutely infected with Trypanosoma cruzi. Revista da Sociedade Brasileira de Medicina Tropical 27:19-24, jan-mar, 1994.

Diets used and experimental design. The diets $(19 \%, 14.25 \%, 9.5 \%$ and $4.75 \%$ of protein) differred only in the amount of protein (soy bean protein supplemented with D-methionine), being otherwise equivalent and were admnistered ad libitum (Table 1).

Table 1 - Basic components used in diets.

\begin{tabular}{lrrrr}
\hline & \multicolumn{4}{c}{ Total protein (\%) } \\
\cline { 2 - 5 } Components (\%) & 19.00 & 14.25 & \multicolumn{1}{c}{9.50} & 4.75 \\
\hline Soy bean protein $^{1}$ & 23.75 & 17.81 & 11.90 & 6.75 \\
Saccharose $^{2}$ & 60.00 & 65.00 & 71.00 & 76.00 \\
Corn oil $^{3}$ & 2.00 & 2.00 & 2.00 & 2.00 \\
Fibers $^{4}$ & 10.00 & 10.00 & 10.00 & 10.00 \\
Methionin $_{\text {Mineral mix }}^{5}$ & 0.24 & 0.20 & 0.10 & 0.08 \\
Vitamin mix $^{5}$ & 5.00 & 5.00 & 5.00 & 5.00 \\
\hline
\end{tabular}

1: isolated soy bean protein ( $80 \%$ protein). SANBRA, SP, Brazil; 2: commercial sugar; 3: corn oil Mazzola, Refinações de Milho Brasil, SP, Brazil; 4 : peel rice powder; 5: mineral and vitamin mix Roche, supplemented according the Nutrients Requirements for Laboratory Animals, National Academy of Sciences, Washington, DC, 1978.

Eight groups of mice (ten per group), were maintained on these diets for five weeks, and infected with the Y strain (four groups) or CL strain (four groups) of $T$. cruzi. As the $Y$ strain induces a lethal infection after the second week, the groups infected with this strain were maintained on the same diet until the animals spontaneously died. For the $\mathrm{CL}$ strain the inoculum used induces an acute infection with low mortality. For this reason the $\mathrm{CL}$ infected groups were maintained in the diets for 30 days after infection, when all the survivors were sacrificed. Control non-infected mice of each dietary group were kept simultaneously with the infected groups. Food consumption was randomly verified by weighing the food given, the food remaining and the amount of tood spilt.

Follow up of the infection. All mice were weighed weekly. Parasitemia was evaluated by the method described by Brener ${ }^{1}$ with three or two days intervals after infection, respectively for $\mathrm{CL}$ or $\mathrm{Y}$ strain.
Histopathology. The infected animals which died spontaneously, as well those sacrificed at the end of the experiment, were necropsied. Fragments of heart and skeleton muscle (thigh muscles) were fixed in isotonic Bouin (Bouin liquid diluted at 1:4 in saline) for at least $48 \mathrm{~h}$, embedded in paraffin and stained routinely.

Statistical methods. When necessary the Student's $t$ test was used for comparison of parasitemia and the Wilcoxon test was used for comparison of mortality. Unless otherwise stated the significance level was $p<0.05$.

\section{RESULTS}

The animals maintained in the $19 \%$ protein diet had weight gain before the infection, but there was discrete weigth loss during the period of infection. The protein deprived, non infected groups, had no weight gain (moderate protein restriction or $14.25 \%$ ) or a weight loss no higher than $30 \%$ of the initial body weight. After infection there was weight loss, more accentuated in the groups with severe protein restriction ( 9.5 and $4.75 \%$ of protein). None of the control non infected mice died spontaneously during the follow up of infected groups.

Parasitemia was higher in groups mantained on severe protein restriction ( $4.75 \%$ ) for both CL and $\mathrm{Y}$ strains. The groups maintained on moderate protein deprivation presented parasitemia similar to that of normally nourished groups (Figures 1 and 2).

The mortality of mice infected with the Y strain was higher and earlier in the severe protein restricted group $(4.75 \%$ protein). For the other protein restricted groups the mortality was similar to that observed in normally nourished animals (Figure 3). In mice infected with the CL strain mortality was observed until the $30^{\text {th }}$ day of infection and was significantly higher in the group with severe protein restriction ( $4.75 \%$ of protein). The groups with moderate protein restriction presented mortality similar to the normally nourished group (Figure 4).

The microscopic study of the groups infected with the Y strain, all of which died spontaneously, showed no differences in the lesions of heart and skeleton muscle. Scarce inflammatory foci were observed and parasites in the muscle cells were infrequent, both in normally nourished and in 
Gomes NGL, Pereira FEL, Domingues GCS, Alves JR. Effects of severe protein restriction in levels of parasitemia and in mortality of mice accutely infected with Trypanosoma cruzi. Revista da Sociedade Brasileira de Medicina Tropical 27:19-24, jan-mar, 1994.

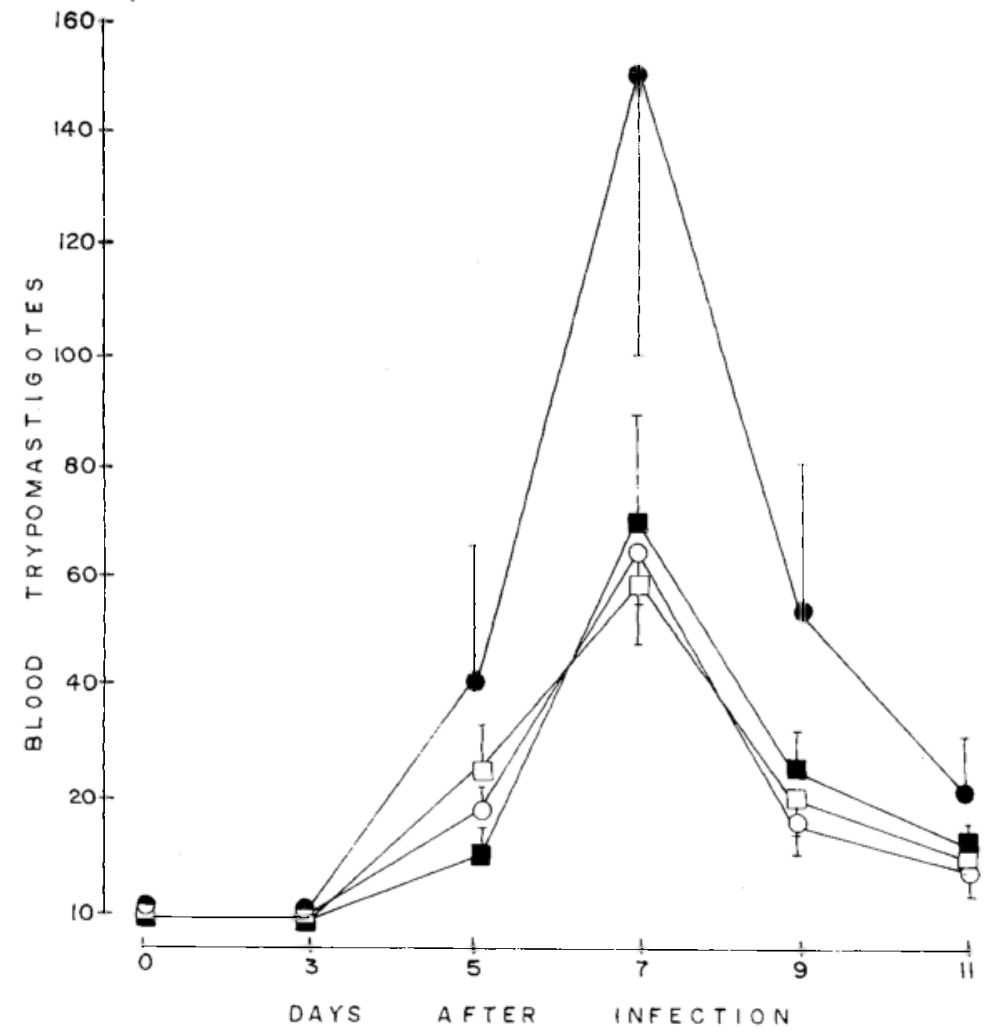

Figure 1 - Parasitemia in mice submitted to protein deprivation and infected with $Y$ strain of Trypanosoma cruzi (mean \pm one standard deviation of the number of the blood trypomastigotes counted in 50 high power microscopic fields 400X). The differences observed between the $4.75 \%$ protein group and the other groups are significant (Student's t test: $p<0.05$ ).

- $4.75 \%$ protein

O $9.50 \%$ protein

$\square 14.25 \%$ protein

$19.00 \%$ protein

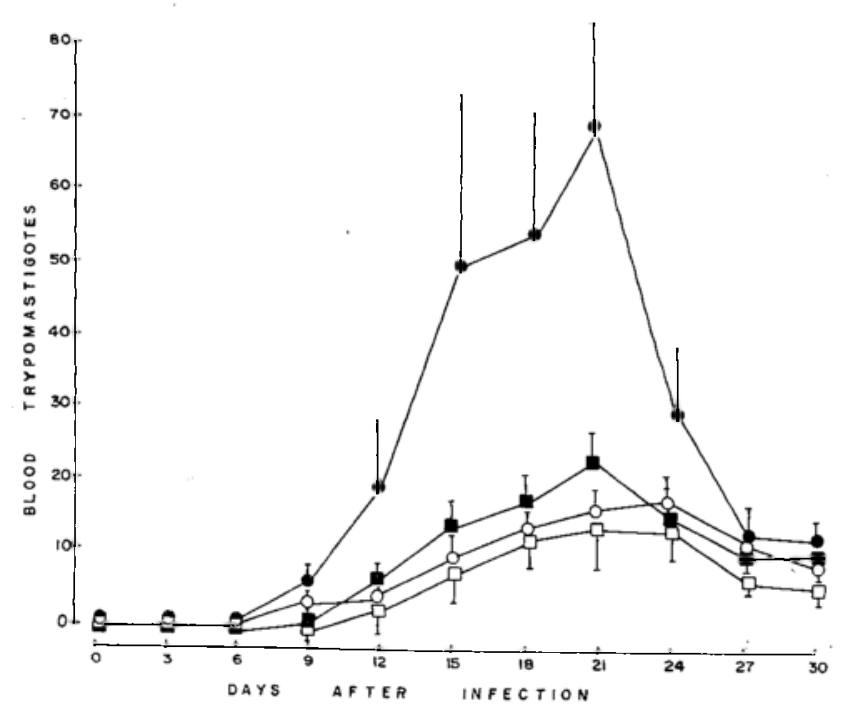

Figure 2 - Parasitemia in mice submitted to protein deprivation and infected with CL strain of Trypanosoma cruzi (mean \pm one standard deviation of the number of the blood trypomastigotes counted in 50 high power microscopic fields 400X). The differences observed between the $4.75 \%$ protein group and the other groups are significant (Student's t test: $p<0.05$ ).

$4.75 \%$ protein $\bigcirc 9.50 \%$ protein $14.25 \%$ protein $19.00 \%$ protein 
Gomes NGL, Pereira FEL, Domingues GCS, Alves JR. Effects of severe protein restriction in levels of parasitemia and in mortality of mice accutely infected with Trypanosoma cruzi. Revista da Sociedade Brasileira de Medicina Tropical 27:19-24, jan-mar, 1994.

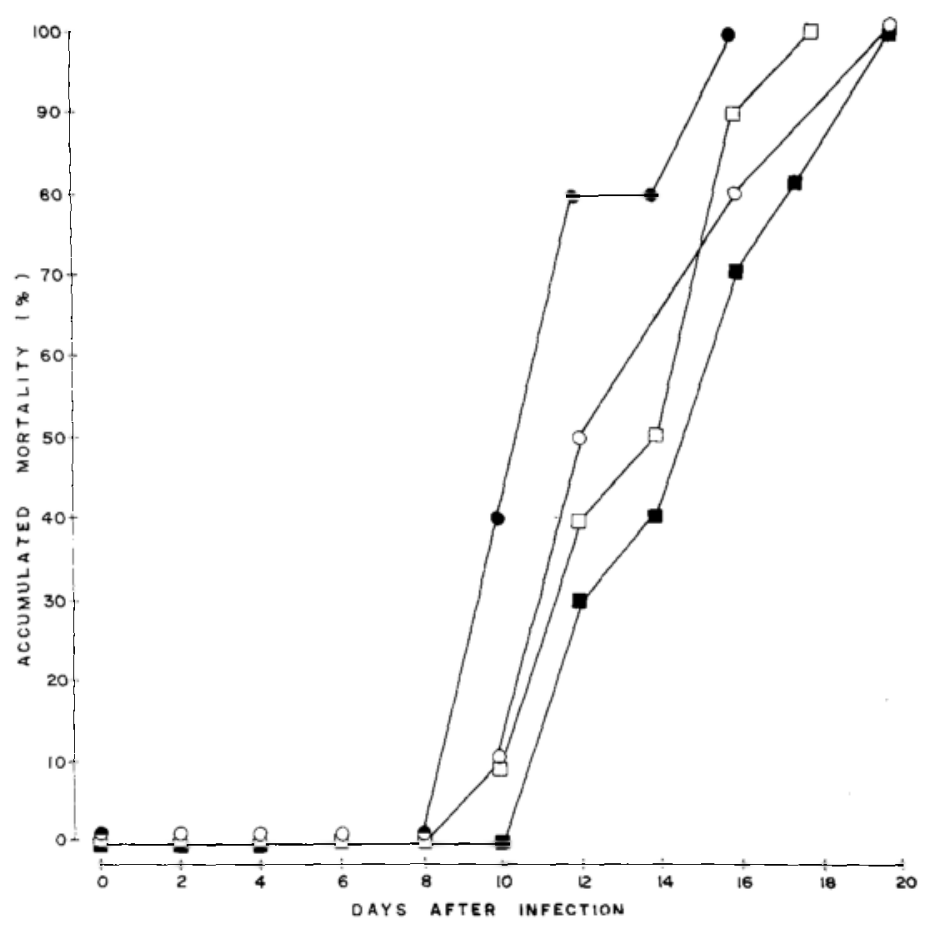

Figure 3 - Accumulated mortality among mice submitted to protein deprivation and infected with $Y$ strain of Trypanosoma cruzi. The differences observed between the $4.75 \%$ protein group and the other groups are significant (Wilcoxon test: $p<0.05$ ).

$4.75 \%$ protein $\bigcirc 9.50 \%$ protein

$\square 14.25 \%$ protein $19.00 \%$ protein

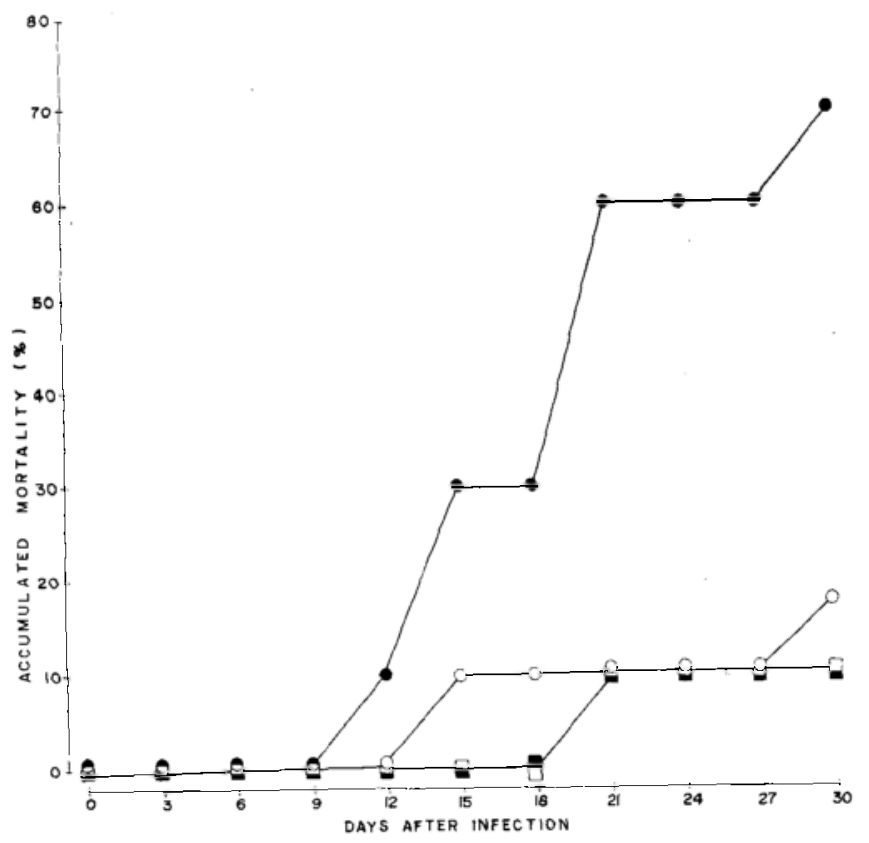

Figure 4 - Accumulated mortality among mice submitted to protein deprivation and infected with $C Z$ strain of Trypanosoma cruzi. The differences observed between the $4.75 \%$ protein group and the other groups are significant Wilcoxon test: $p<0.05$ ).

$4.75 \%$ protein

O $9.50 \%$ protein $14.25 \%$ protein

$19.00 \%$ protein 
Gomes NGL, Pereira FEL, Domingues GCS, Alves JR. Effects of severe protein restriction in levels of parasitemia and in mortality of mice accutely infected with Trypanosoma cruzi. Revista da Sociedade Brasileira de Medicina Tropical 27:19-24, jan-mar, 1994.

protein deficient groups. In the groups infected with the CL strain there was a higher frequency of parasites in the muscle cells of the severe protein restricted group although the inflammatory lesions seemed to be less extensive than those observed in normally nourished groups (19\% protein) or in groups with moderate protein deprivation.

\section{DISCUSSION}

The results showed that only severe protein restriction ( $4.75 \%$ of protein) increased parasitemia and mortality after Trypanosoma cruzi infection in mice. Less severe or moderate protein restriction did not modify the evolution of infection with $T$. cruzi at least in respect to parasitemia, mortality and inflammatory lesions in the heart and skeleton muscle. It is possible that the duration of protein restriction before infection -5 weeks - had not been sufficient to interfere with the mechanisms of resistance to infection in the groups submitted to less severe protein restriction (14.75 and $9.5 \%$ of protein).

Protein deprivation can induce reduction in cell mediated and humoral immune response that is related to the severity of protein restriction and the period of time on restricted diet ${ }^{4}$. Moderate protein restriction, mainly for short periods, not only maintains but can enhance the immune response, specially cellular mechanisms ${ }^{6}$. Our results agree with these observations showing that the more severe the protein restriction the more severe the reduction in defense mechanisms against the infection with $T$. cruzi.

Despite the increased number of parasites in the muscle cells of the $4.75 \%$ protein group infected with the CL strain, the inflammatory reaction was less severe than in the other groups infected with the same strain. This mild inflammatory reaction could be due to the reduction of cell mediated immunity induced by severe protein restriction. It is well known that cell mediated immune mechanisms play an important role on the pathogenesis of inflammatory lesions in Chagas' disease $\mathrm{P}^{11} 12131415$.

Further studies are necessary to elucidate the immune mechanisms against $T$. cruzi in protein restricted animals.

\section{RESUMO}

Camundongos albinos adultos foram submetidos a dietas com diferentes concentrações de proteína $(4,75 \%$, $9,5 \%, 14,25 \%$ e $19 \%$ de proteína em dietas isocalóricas com quantidades normais de minerais e vitaminas) durante cinco semanas e em seguida infectados com duas cepas do Trypanosoma cruzi: $10^{5}$ tripomastigotas da cepa $\mathrm{Y}$ ou $10^{4}$ tripomastigotas da cepa CL. Os animais foram mantidos com as mesmas dietas e a infecção foi seguida com avaliação da parasitemia, da mortalidade $e$ das lesões no coração e no músculo esquelético. Somente a restrição protéica severa $(4,75 \%$ de proteina) induziu redução significante da resistência à infecção com as duas cepas utilizadas, o que foi demonstrado pela maior parasitemia e maior mortalidade. As lesôes inflamatórias no coração eno músculo esquelético foram menos extensas nos animais submetidos à desnutrição protéica severa apesar do maior parasitismo das células musculares nesses animais. A depressão da resposta imunitária celular induzida pela desnutrição protéica seria responsável pela diminuição da resistência ao parasita e pela redução da intensidade da reação inflamatória observada.

Palavras-chaves: Desnutrição. Doença de Chagas. Trypanosoma cruzi.

\section{REFERENCES}

1. Brener $Z$. Contribuição ao estudo da terapêutica experimental da doença de Chagas. Tese de Doutorado. Universidade Federal de Minas Gerais. Belo Horizonte, 1961.

2. Chandra RK. Nutrition, immunity and infection: present knowledge and future directions. Lancet 1:688-691, 1983.

3. Edirisinghe JS, Fern EB, Targett GAT. Dietary suppression of rodent malaria. Transactions of the Royal Society of Tropical Medicine and Hygiene 79:591-593, 1981.

4. Kahan BD. Nutrition and host defense mechanisms. Surgical Clinics of North America 61:557-570, 1981.

5. Machado CRS, Moraes-Santos T, Machado ABM. Cardiac noradrenalin in relation to experimental Chagas' disease in the rat. The American Journal of Tropical Medicine and Hygiene 33:835-838, 1984.

6. Malave I, Pocino M. Nutrition and dysregulation of the immune response. In: Beers Jr RF, Basset EG (eds) Nutritional factors modulating effects of metabolic process. Raven Press, New York p.383, 1981.

7. Melo RC, Brener Z. Tissue tropism of different 
Gomes NGL, Pereira FEL, Domingues GCS, Alves JR. Effects of severe protein restriction in levels of parasitemia and in mortality of mice accutely infected with Trypanosoma cruzi. Reyista da Sociedade Brasileira de Medicina Tropical 27:19-24, jan-mar, 1994.

Trypanosoma cruzi strains. Journal of Parasitology 64:475-482, 1978.

8. Perez $\mathrm{H}$, Malave I. Protein malnutrition and susceptibility to leishmaniasis and other protozoan diseases. African Journal of Clinical and Experimental Immunology 2:1-7, 1981.

9. Perez H, Malave I, Beverly A. The effects of protein malnutrition on the course of Leishmania mexicana infection in $\mathrm{C}_{57} \mathrm{~B} 1 / 6$ mice: nutrition and susceptibility to leishmaniasis. Clinical and Experimental Immunology 38:453-460, 1979.

10. Platt BS, Dema IS, Miller DS. Effect of protein values of the diet on the course of malaria infection (Plasmodium berghei) in rats. Proceedings of Nutrition Society 19:97-105, 1960.

11. Santos RR, Laus JL, Mengel JG, Savino W. Chronic Chagas cardiopathy: role of CD4 $\mathrm{T}$ cells in the anti heart autoreactivity. Memórias do Instituto Oswaldo Cruz 85:367-369, 1990.

12. Santos RR, Pirmez C, Savino W. Role of autoreactive immunological mechanisms in chagasic carditis. Research in Immunology 142:134-137, 1991.

13. Santos-Busch CA, Teixeira ARL. The immunology of experimental Chagas' disease. III-Rejection of allogeneic heart cells in vitro. Journal of Experimental Medicine 140:38-53, 1974.
14. Teixeira ARL, Teixeira L, Macedo V, Prata A. Trypanosoma cruzi sensitized $\mathrm{T}$ lymphpcytes mediated $\mathrm{Cr}$ release from human heart cells in Chagas' disease. The American Journal of Tropical Medicine and Hygiene 27:1097-1107, 1978.

15. Teixeira ARL, Teixeira L, Santos Busch CA. The immunology of experimental Chagas' disease. IVProduction of lesions in rabbits similar to those of chronic Chagas' disease in man. American Journal of Pathology 80:163-178, 1975.

16. Yaeger Y, Miller ON. Effects of malnutrition on suscepibility of rats to Trypanosoma cruzi. IThyamine deficiency. Experimental Parasitology 9:215-222, 1960.

17. Yaeger Y, Miller ON. Effects of malnutrition on susceptibility of rats to Trypanosoma cruzi. IIRiboflavin deficiency. Experimental Parasitology 10:227-231, 1960.

18. Yaeger, Y, Miller ON. Effects of malnutrition on susceptibility of rats to Trypanosoma cruzi. IIIPantothenate deficiency. Experimental Parasitology 10:232-237, 1960.

19. Yaeger Y, Miller ON. Effects of malnutrition on susceptibility of rats to Trypanosoma cruzi. IVPyridoxine deficiency. Experimental Parasitology 10:238-244, 1960. 